\title{
Diagnostic utility of immunohistochemistry in distinguishing trichoepithelioma and basal cell carcinoma: evaluation using tissue microarray samples
}

\author{
Antonio José Tebcherani ${ }^{1,2,3}$, Heitor Franco de Andrade Jr${ }^{1}$ and Mirian N Sotto ${ }^{1}$ \\ ${ }^{1}$ University of São Paulo Medical School, São Paulo, SP, Brazil; ${ }^{2}$ Francisco Morato Hospital São Paulo, \\ São Paulo, SP, Brazil and ${ }^{3}$ Padre Bento Hospital, Guarulhos, SP, Brazil
}

\begin{abstract}
Trichoepithelioma is a benign neoplasm that shares both clinical and histological features with basal cell carcinoma. It is important to distinguish these neoplasms because they require different clinical behavior and therapeutic planning. Many studies have addressed the use of immunohistochemistry to improve the differential diagnosis of these tumors. These studies present conflicting results when addressing the same markers, probably owing to the small number of basaloid tumors that comprised their studies, which generally did not exceed 50 cases. We built a tissue microarray with 162 trichoepithelioma and 328 basal cell carcinoma biopsies and tested a panel of immune markers composed of CD34, CD10, epithelial membrane antigen, Bcl-2, cytokeratins 15 and 20 and D2-40. The results were analyzed using multiple linear and logistic regression models. This analysis revealed a model that could differentiate trichoepithelioma from basal cell carcinoma in $36 \%$ of the cases. The panel of immunohistochemical markers required to differentiate between these tumors was composed of CD10, cytokeratin 15, cytokeratin 20 and D2-40. The results obtained in this work were generated from a large number of biopsies and resulted in the confirmation of overlapping epithelial and stromal immunohistochemical profiles from these basaloid tumors. The results also corroborate the point of view that trichoepithelioma and basal cell carcinoma tumors represent two different points in the differentiation of a single cell type. Despite the use of panels of immune markers, histopathological criteria associated with clinical data certainly remain the best guideline for the differential diagnosis of trichoepithelioma and basal cell carcinoma.
\end{abstract}

Modern Pathology (2012) 25, 1345-1353; doi:10.1038/modpathol.2012.96; published online 8 June 2012

Keywords: basal cell carcinoma; immunohistochemistry; linear multinomial analysis; regression multinomial analysis; small biopsies; tissue microarray; trichoepithelioma

There are many histological similarities shared by basal cell carcinoma and the follicle tumors, particularly trichoepithelioma. ${ }^{1}$

The correct diagnosis between these tumors is very important because basal cell carcinoma is a locally aggressive neoplasm and must be totally excised with safe margins. However, trichoepithelioma is a benign neoplasm, which may be partially excised by shaving.

Correspondence: Dr MN Sotto, MD, Dermatology, University of São Paulo, Avenida Dr Arnaldo, 455 - sala 1118, CEP: 01246-903, São Paulo, SP, Brazil.

E-mail: mnsotto@usp.br

Received 16 January 2012; revised 30 March 2012; accepted 1 April 2012; published online 8 June 2012
Many authors have addressed the question 'basal cell carcinoma $\times$ benign tumors from the pilar unit' using immunohistochemical techniques in hopes of improving the diagnosis of these tumors. ${ }^{2-15}$

With exception of D2-40 labeling, ${ }^{14}$ the studies present conflicting findings when comparing results for the same immunohistochemical markers. This may be due to the small number of basaloid tumors that comprised their casuistics.

In this study, we proposed to build a tissue microarray with trichoepithelioma and basal cell carcinoma biopsies to verify the applicability of the proposed immunohistochemical markers for the differential diagnosis of these two basaloid tumors by studying a large series of specimens. 



Figure 1 (a) Trichoepithelioma: basaloid cellular nodules, papillary mesenchymal bodies, clefting between the stromal tumor and the reticular dermis and cysts filled with keratin. (b) Micronodular basal cell carcinoma: small nests of basaliomatous cells. (c) Trichoepithelioma with CD34 immunostaining in the peripheral stroma of the cellular nodules. (d) Basal cell carcinoma displaying CD34 expression in the stroma surrounding the basaliomatous nodules. (e) Trichoepithelioma with peripheral basaloid cells showing the Bcl-2 staining pattern. (f) Basal cell carcinoma showing the Bcl-2 immunostaining of the peripheral cells of tumoral nests.

\section{Materials and methods}

The study was approved by the Institutional Review Boards of the three institutions involved (University of São Paulo Medical School, Francisco Morato Hospital and Padre Bento Hospital).

The studied cases comprise 162 specimens of classic trichoepithelioma. All the biopsies were reviewed, and the tumor areas displaying trichoepithelioma characteristics were punched. These were mainly basaloid neoplastic islands that were arranged in lobules, associated with papillary mesenchymal bodies and that formed clefts between the stromal tumor and the reticular dermis (Figure 1a).

The basal cell carcinoma group was composed of 328 specimens. The basal cell carcinomas were classified as nodular $(n=145)$, micro-nodular ( $n=57)$, sclerosing $(n=63)$, mixed-type nodular and micro-nodular $(n=59)$, nodular and sclerosing $(n=03)$, and micro-nodular and sclerosing $(n=01)$. The punched areas of the nodular basal cell carcinoma biopsies used to build the tissue microarray had clusters of basaliomatous cells that 
Table 1 The specifications, dilutions and antigen retrieval procedures for the antibodies

\begin{tabular}{|c|c|c|c|c|}
\hline Antibody & Code/clone & Company & Dilution & Antigen retrieval \\
\hline CD34 & M7165/clone QBEnd-10 & $\begin{array}{l}\text { DAKO Cytomation } \\
\text { (Carpinteria, CA, USA) }\end{array}$ & $1 / 500$ & $10 \mathrm{mM}$ citric acid, $\mathrm{pH} 6.0^{\mathrm{a}}$ \\
\hline Bcl-2 & 18-0193Z/Bcl-2-100 & Zymed (CA, USA) & $1 / 400$ & $10 \mathrm{mM}$ citric acid, $\mathrm{pH} 6.0$ \\
\hline CD10 & $\begin{array}{l}\text { MS-728-S/CALLA Ab-2, } \\
\text { clone 56C6 }\end{array}$ & $\begin{array}{l}\text { Thermo Fisher Scientific } \\
\text { (USA) }\end{array}$ & $1 / 100$ & $1 \mathrm{mM}$ EDTA, pH $8.0^{\mathrm{b}}$ \\
\hline $\begin{array}{l}\text { Epithelial } \\
\text { membrane } \\
\text { antigen }\end{array}$ & M0613/clone E29 & $\begin{array}{l}\text { DAKO Cytomation } \\
\text { (Carpinteria, CA, USA) }\end{array}$ & $1 / 1000$ & $10 \mathrm{mM}$ citric acid, $\mathrm{pH} 6.0^{\mathrm{a}}$ \\
\hline Cytokeratin 20 & M7019/KS20.8 & $\begin{array}{l}\text { DAKO Cytomation } \\
\text { (Carpinteria, CA, USA) }\end{array}$ & $1 / 800$ & $10 \mathrm{mM}$ citric acid, $\mathrm{pH} 6.0^{\mathrm{a}}$ \\
\hline Cytokeratin 15 & NCL-CK15 & $\begin{array}{l}\text { Novocastra (Newcastle, } \\
\text { UK) }\end{array}$ & $1 / 50$ & $10 \mathrm{mM}$ citric acid, $\mathrm{pH} 9.0^{\mathrm{a}}$ \\
\hline $\begin{array}{l}\text { D2-40 } \\
\text { (podoplanin) }\end{array}$ & M3619 & $\begin{array}{l}\text { DAKO Cytomation } \\
\text { (Carpinteria, CA, USA) }\end{array}$ & $1 / 600$ & $10 \mathrm{mM}$ citric acid, $\mathrm{pH} 6.0^{\mathrm{a}}$ \\
\hline
\end{tabular}

${ }^{\mathrm{a}}$ In microwave oven.

${ }^{\mathrm{b}}$ In steamer. Novocastra Novolink Polymer Detection Systems, code RE7150-CE (Leica Microsystems, Newcastle upon Tyne, UK), was the detection system used in all the reactions. The reactions were visualized with 3,3-diaminobenzidine tetrachloride (Sigma Chemical Company, USA), followed by light counterstaining with Harris hematoxylin.

exhibited peripheral layers of columnar cells with palisaded nuclei, single cell or massive necrosis, a fast mitotic rate and cleaving between tumor islands and the surrounding mucin-rich stroma. The micronodular basal cell carcinoma specimens displayed small basaliomatous cells clusters (Figure 1b), and the sclerosing (morpheaform) tumors were composed of strands of basaloid cells immersed in a dense and hyalinized dermal stroma.

The tissue microarrays were performed using a manual tissue arrayer (MTA-1, Beecher Instruments, WI, USA). Each tissue microarray was mounted in duplicate. Fifty-one $5-\mu \mathrm{m}$ sections from each tissue microarray block were transferred to silanized $26 \times 76 \mathrm{~mm} \times 1.0 \mathrm{~mm}$ glass microscope slides with colored edges from StarFrost-Adhäsiv (Bad Homburg, Germany).

Four slides obtained from the initial level (one slide), medium level (two slides) and the end of the tissue microarray block (one slide) were stained with hematoxylin and eosin to evaluate the samples and to choose the most representative sequential slides for immunohistochemical staining. The specification of the antibodies used, the code/clone, the company, the titration and the procedure for antigen retrieval are displayed in Table 1 . All the reactions were revealed with 10\% 3, 3-diaminobenzidine tetrachloride as a chromogen (Sigma, Chemical Company, St Louis, MO, USA), hydrogen peroxide with $1 \%$ dimethyl sulfoxide (Labsynth, Diadema, SP, Brazil) and phosphate-buffered saline followed by light counterstaining with Harris hematoxylin. Positive and negative controls for each antibody in every batch of slides were examined to insure the adequacy of the immunohistochemical reactions.

All the stained slides were digitalized using the Aperio Scan Scope slide scanner (Vista, CA, USA). The obtained digital slides were examined using the Aperio's Image Scope Viewer software. This approach allowed for a quick and blind evaluation of each stained TMA by two independent observers. The staining was considered negative if $<25 \%$ of the tumor cells or stroma were immunostained. The cellular patterns of the staining were evaluated by the cytoplasmic expression of the antigen in peripheral cells layers or by diffuse expression in central basaloid cells. Diffuse stromal staining and peritumoral immune labeling was considered positive stromal staining.

The data from the immunohistochemical evaluation of each sample were analyzed initially by chi-square and Fisher's exact tests $(P \leq 0.05$ was considered statistically significant). Subsequently, the same data were analyzed by multiple linear regression models using the Statistica 7.1 package (StatSoft, Tulsa, USA) and the strength of each individual test in the confirmed diagnosis of trichoepithelioma or basal cell carcinoma was investigated. This exploratory analysis was also confirmed by multiple logistic regressions of the qualitative data using Stata SE 10.0. (Stata Corp LP, College Station, USA). The association of the significant variables was analyzed using a chisquare test.

\section{Results}

The 162 trichoepithelioma tumors were taken from 53 men and 109 women. In 26 cases, there were multiple lesions, ranging from two to four lesions per patient. The age of patients ranged from 7 to 74 years (mean age $=56$ years). The most frequent skin sites of trichoepithelioma were as follows: nose, upper lip, eyelid, other regions of the face and the malar region.

The basal cell carcinoma group was comprised of 176 men and 152 women. The age of the patients ranged from 27 to 90 years. The average age was 66 years. The most frequent sites of basal cell carcino- 
ma tumors were nose, the malar region, forehead, upper limb and dorsum.

\section{Immunohistochemical Evaluation}

One hundred and forty-four trichoepithelioma biopsies and 302 basal cell carcinoma biopsies were subjected to CD34 immunostaining. Positive CD34 staining was found in 109 (76\%) trichoepithelioma and 137 (45\%) basal cell carcinoma biopsies. Eighty-two trichoepithelioma (57\%) and 90/302 $(30 \%)$ basal cell carcinoma biopsies displayed CD34 labeling in the peritumoral stroma (Figures 1c and d). Staining of all the represented stroma was the second most frequent staining pattern. This pattern was observed in 13/144 (9\%) trichoepithelioma and 39/302 (13\%) basal cell carcinoma biopsies. In a few cases, the staining of both the basaloid cells and the stroma or only the basaloid cells was observed.

Bcl-2 staining was performed on 143 trichoepithelioma and 317 basal cell carcinoma biopsies, which resulted in 142 (99\%) trichoepithelioma and 311 (98\%) basal cell carcinoma biopsies with positive staining for Bcl-2. In 128 trichoepithelioma and 294 basal cell carcinoma biopsies, clusters of basaloid cells displayed Bcl-2 labeling. Only 14 trichoepithelioma and 17 basal cell carcinoma biopsies showed Bcl-2 expression only in the peripheral basaloid cells of the tumor nests (Figures 1e and f).

CD10 immune staining was performed on 144 trichoepithelioma and 310 basal cell carcinoma biopsies. Of these, 137 (95\%) trichoepithelioma and 307 (99\%) basal cell carcinoma biopsies were reactive for CD10. CD10 most frequently labeled tumor stroma, with positive readings in 87/144 (60\%) trichoepithelioma and 70/310 (23\%) basal cell carcinoma biopsies (Figures 2a and b). CD10 staining was present in both the basaloid cells and the stroma in 38/144 (26\%) trichoepithelioma and 159/310 (51\%) basal cell carcinoma biopsies. CD10 staining of only the basaloid cells was observed in 12/144 (8\%) trichoepithelioma and 78/310 (25\%) basal cell carcinoma biopsies.

Positive expression of epithelial membrane antigen was found in 149/155 (96\%) trichoepithelioma and 292/307 (95\%) basal cell carcinoma biopsies. The tumor cells and stroma were stained in 115 (74\%) trichoepithelioma and 170 (55\%) basal cell carcinoma biopsies (Figures 2c and d). Epithelial membrane antigen expression by basaloid cells was observed in 34 trichoepithelioma and 122 basal cell carcinoma biopsies.

Only 29/151 (19\%) trichoepithelioma and 14/311 (4\%) basal cell carcinoma biopsies exhibited cells with cytokeratin 20-labeled cytoplasm. These cells were observed at the outermost layer of the basaloid clusters of both tumors (Figures 2e and f).

Cytokeratin 15 was used to stain 140 trichoepithelioma and 304 basal cell carcinoma biopsies. The 131 (94\%) cytokeratin 15-positive trichoepithelioma biopsies showed staining of all the basaloid cells in 56 tumors $(40 \%)$. Seventy-five cases (54\%) displayed cytokeratin 15 immunoexpression in only the outermost peripheral tumor cells (Figure 3a). Of the basal cell carcinoma biopsies, 196 (64\%) were immunoreactive for cytokeratin 15. Of these, 156 samples $(51 \%)$ displayed staining in all the tumor cells. The expression of cytokeratin 15 only in the cells at the periphery of the tumor islands (Figure 3b) was observed in 40 (13\%) tumors.

D2-40 was used to stain 143 trichoepithelioma and 307 basal cell carcinoma biopsies, of which 91/ $143(64 \%)$ trichoepithelioma biopsies stained positive for D2-40. Eighty-six (60\%) trichoepithelioma biopsies displayed podoplanin expression in the outermost peripheral basaloid cells (Figure 3c). Only $5(3 \%)$ trichoepithelioma biopsies showed D2-40 immunostaining in all the tumor cells. On the other hand, only 18 samples (6\%) basal cell carcinoma biopsies were positive for D2-40. In 13 $(4 \%)$ tumors, podoplanin expression was observed in the peripheral basaliomatous cells (Figure 3d), and $5(2 \%)$ basal cell carcinoma biopsies showed staining of all the tumor cells.

There were few biopsy losses in each group. Of all the biopsies tested, 140/155 trichoepithelioma and 302/311 basal cell carcinoma biopsies were subjected to all seven markers.

\section{Statistical Analysis}

All the significant results observed by comparison of trichoepithelioma and basal cell carcinoma (Table 2) were included in a multiple association model (Table 3).

This analysis indicated that both the stromal expression of CD34 and CD10 and the expression of cytokeratin 20, 15 and D2-40 in peripheral tumor cells were associated with a better chance of an accurate trichoepithelioma diagnosis. However, epithelial membrane antigen and Bcl-2 were not useful for discriminating between trichoepithelioma and basal cell carcinoma.

The best marker in the individual analysis was D240 , with a Beta value -0.46 . The next best markers for discriminating between these two tumors were cytokeratin 15, CD10, and cytokeratin 20 with Beta of values $-0.23,-0.18$, and -0.12 , respectively. The worst of the significant markers in this analysis was CD34, with a Beta value of -0.097 . The Bcl-2 and epithelial membrane antigen patterns/markers were not significant (Beta value $=-0.032$ for each marker).

Based on these data, we excluded the nonsignificant immune stains in the complete model, which is summarized in Table 4 .

To verify the usefulness of an immune labeling panel consisting of the antibodies tested above, we assembled the immunohistochemical markers/ patterns observed in trichoepithelioma and basal cell carcinoma that were previously selected by 



Figure 2 (a) Trichoepithelioma displaying CD10 staining of the stroma around basaloid nests. (b) Basal cell carcinoma with the same CD10 expression pattern. (c) Trichoepithelioma with epithelial membrane antigen immunolabeling of both basaloid cells and the surrounding stroma. (d) Basal cell carcinoma showing epithelial membrane antigen expression in both the cellular and stromal components. (e) Trichoepithelioma exhibiting cytokeratin 20-labeled cells scattered at the outermost layer of basalolid nodules. (f) The same immunolabeled pattern was observed in basal cell carcinoma.

logistic regression analysis of each tumor. These panels were named Labeling Immunohistochemical Groups. These arrangements aimed to identify the smallest group of markers that could discriminate the largest population of trichoepithelioma. The discrimination of trichoepithelioma was possible when all the basal cell carcinoma were excluded (ie, none of the basal cell carcinoma displayed the immunohistochemical maker/pattern).

The first group, designated Labeling Immunohistochemical Group 0, was comprised of only D2-40 labeling and failed to distinguish between trichoepithelioma and basal cell carcinoma.

Labeling Immunohistochemical Group 1 was comprised of the D2-40 and cytokeratin 15 markers. The tumors were classified as subsets 0 (negative for both markers), 1 (positive for one of the two markers) or 2 (positive for both markers). This combination was not useful for differentiating trichoepithelioma from basal cell carcinoma.

Labeling Immunohistochemical Group 2 consisted of the D2-40, cytokeratin 15 and CD10 

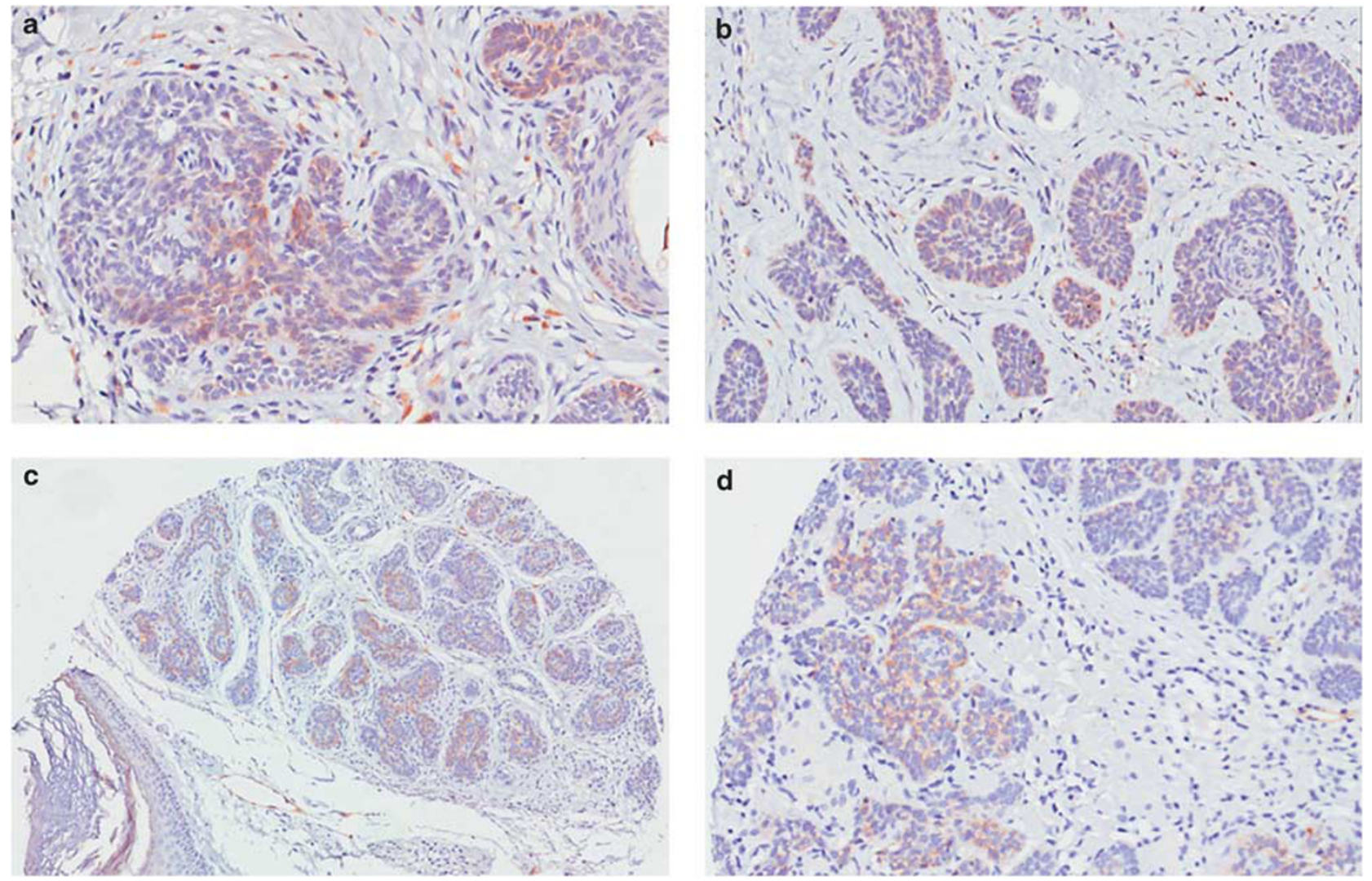

Figure 3 (a) Trichoepithelioma showing cytokeratin 15 immunolabeled cells of the outermost layer of the basaloid lobules. (b) Basal cell carcinoma with the same immunolabeled pattern. (c) Trichoepithelioma displaying D2-40 staining of the peripheral basaloid cells. (d) Basal cell carcinoma with the same pattern of D2-40 immunostaining.

markers, and the analysis was performed in the same manner. Each tumor was classified as subsets 0 (negative for the three markers), 1 (positive for only one marker), 2 (positive for two markers) and 3 (positive expression of all 3 markers). This combination was better able to distinguish between the tumors; the group positive for all three markers was able to identify $32 / 128$ (25\%) of the trichoepithelioma tumors, and none of the basal cell carcinoma tumors exhibited this panel pattern.

Labeling Immunohistochemical Group 3 was comprised of the D2-40, cytokeratin 15, CD10 and cytokeratin 20 markers. The tumors were classified as subsets 0 (negative for all the markers), 1 (positive for only one marker), 2 (positive for two markers), 3 (positive for three markers) and 4 (positive for all four markers). In Labeling Immunohistochemical Group 3, positive expression of 3 or 4 immune markers were able to distinguish $36 \%(46 / 128)$ of the trichoepithelioma biopsies.

Labeling Immunohistochemical Group 4 was comprised of a panel of D2-40, cytokeratin 15, CD10, cytokeratin 20 and CD34 markers. In Labeling Immunohistochemical Group 4, positive expression of 4 or 5 immune markers enabled the differentiation of $27 \%$ of the trichoepithelioma biopsies from the basal cell carcinoma biopsies.

\section{Discussion}

We devised a systematic analysis of immunohistochemical markers to distinguish trichoepithelioma biopsies from basal cell carcinoma biopsies using a large series of both tumors. Our tissue microarray data set is probably the largest to verify the reliability of these markers, either isolated or combined in panels, to distinguish trichoepithelioma biopsies from basal cell carcinoma biopsies.

Previous studies indicated that stromal staining of CD34 is helpful in distinguishing trichoepithelioma from basal cell carcinoma tumors. ${ }^{5}$ However, in our study, comparing stromal CD34 expression with other markers using logistic regression eliminated this proposition. CD34 was the least efficient antigen in discriminating between trichoepithelioma and basal cell carcinoma tumors. Its inclusion did not improve the efficiency of Labeling Immunohistochemical Group 4 compared with Labeling Immunohistochemical Group 3 (Table 4). Our results, based on a tissue microarray analysis, suggest that CD34 is not a reliable marker to distinguish trichoepithelioma from basal cell carcinoma.

Our results suggest that stromal CD10 staining may be considered in a panel of markers to improve 
Table 2 Expression patterns of CD34, CD10, BCL-2, epithelial membrane antigen, cytokeratin 20, cytokeratin 15 and D2-40 in basal cell carcinoma and trichoepithelioma

\begin{tabular}{|c|c|c|c|c|}
\hline \multirow[t]{2}{*}{ Marker/pattern of expression } & \multirow[t]{2}{*}{ Trichoepithelioma } & \multirow[t]{2}{*}{ Basal cell carcinoma } & \multicolumn{2}{|c|}{ Individual statistical significance } \\
\hline & & & $\mathrm{P}$ value & Odds ratio \\
\hline CD34 & $(n=144)$ & $(n=302)$ & (Fisher's exact test) & \\
\hline Non-immunoreactive & $35(24 \%)$ & $165(55 \%)$ & $P<0.001$ & 0.26 \\
\hline Immunoreactive & $109(76 \%)$ & $137(45 \%)$ & $P<0.0001$ & 3.75 \\
\hline Stroma and tumor cells & $10(7 \%)$ & $4(1 \%)$ & $P=0.002$ & 5.6 \\
\hline Peritumoral stroma & $82(57 \%)$ & $90(30 \%)$ & $P<0.001$ & 3.1 \\
\hline Stroma & $13(9 \%)$ & $39(13 \%)$ & Not significant & \\
\hline Tumor cells alone & $4(3 \%)$ & $4(1 \%)$ & Not significant & \\
\hline$B c l-2$ & $(n=143)$ & $(n=317)$ & & \\
\hline Non-immunoreactive & $1(1 \%)$ & $6(2 \%)$ & Not significant & \\
\hline Immunoreactive & $142(99 \%)$ & $311(98 \%)$ & Not significant & \\
\hline Diffusely in tumor cells & $128(89 \%)$ & $294(93 \%)$ & Not significant & \\
\hline Peripheral layer of tumor cells nests & $14(10 \%)$ & $17(5 \%)$ & Not significant & \\
\hline$C D 10$ & $(n=144)$ & $(n=310)$ & & \\
\hline Non-immunoreactive & $7(5 \%)$ & $3(1 \%)$ & $P<0.01$ & 5.2 \\
\hline Immunoreactive & $137(95 \%)$ & 307 (99\%) & Not significant & \\
\hline Stroma and tumor cells & $38(26 \%)$ & $159(51 \%)$ & $P<0.0001$ & 0.34 \\
\hline Stroma, no tumor cells & $87(60 \%)$ & $70(23 \%)$ & $P<0.0001$ & 5.23 \\
\hline Tumor cells alone & $12(8 \%)$ & $78(25 \%)$ & $P<0.0001$ & 0.3 \\
\hline Epithelial membrane antigen & $(n=155)$ & $(n=307)$ & & \\
\hline Non-immunoreactive & $6(4 \%)$ & $15(5 \%)$ & Not significant & \\
\hline Immunoreactive & $149(96 \%)$ & $292(95 \%)$ & Not significant & \\
\hline Stroma and tumor cells & $115(74 \%)$ & $170(55 \%)$ & $P<0.001$ & 2.32 \\
\hline Tumor cells alone & $34(22 \%)$ & $122(40 \%)$ & $P<0.001$ & 0.43 \\
\hline Cytokeratin 20 & $(n=151)$ & $(n=311)$ & & \\
\hline Non-immunoreactive & $122(81 \%)$ & $297(95 \%)$ & $P<0.001$ & 0.2 \\
\hline Peripheral layer of tumor cells nests & $29(19 \%)$ & $14(4 \%)$ & $P<0.0001$ & 5.0 \\
\hline Cytokeratin 15 & $(n=140)$ & $(n=304)$ & & \\
\hline Non-immunoreactive & $9(6 \%)$ & $108(35 \%)$ & $P<0.001$ & 0.1 \\
\hline Immunoreactive & $131(94 \%)$ & $196(64 \%)$ & $P<0.0001$ & 8.0 \\
\hline Diffusely in tumor cells & $56(40 \%)$ & $156(51 \%)$ & $P=0.03$ & 0.63 \\
\hline Peripheral layer of tumor cells nests & $75(54 \%)$ & $40(13 \%)$ & $P<0.0001$ & 7.62 \\
\hline$D 2-40$ & $(n=143)$ & $(n=307)$ & & \\
\hline Non-immunoreactive & $52(36 \%)$ & $289(94 \%)$ & $P<0.0001$ & 0.02 \\
\hline Immunoreactive & $91(64 \%)$ & $18(6 \%)$ & $P<0.0001$ & 28.1 \\
\hline Peripheral layer of tumor cells nests & $86(60 \%)$ & $13(4 \%)$ & $P<0.0001$ & 34.1 \\
\hline Diffuse in tumor cells & $5(3 \%)$ & $5(2 \%)$ & Not significant & \\
\hline
\end{tabular}

Table 3 Multiple linear and multiple logistic regression analyses of the immunohistochemical patterns for a trichoepithelioma diagnosis

\begin{tabular}{|c|c|c|c|c|}
\hline \multirow{2}{*}{$\begin{array}{l}\text { Model complete } \\
\text { Complete correlation }\end{array}$} & \multicolumn{2}{|c|}{ Linear } & \multicolumn{2}{|c|}{ Logistic } \\
\hline & \multicolumn{2}{|c|}{$\mathrm{r}^{2}=0.5309$} & \multicolumn{2}{|c|}{ Pseudo $\mathrm{r}^{2}=0.4856$} \\
\hline Antigen & Beta & $\mathrm{P}$ & Odds ratio & $\mathrm{P}$ \\
\hline D2-40 & -0.46 & $<0.0001$ & 3.01 & $<0.0001$ \\
\hline Cytokeratin 15 & -0.23 & $<0.001$ & 1.86 & $<0.001$ \\
\hline CD10 & -0.18 & $<0.001$ & 1.45 & $<0.001$ \\
\hline Cytokeratin 20 & -0.12 & $<0.01$ & 1.42 & $<0.01$ \\
\hline CD34 & -0.097 & $<0.01$ & 0.85 & $<0.05$ \\
\hline Bcl-2 & -0.032 & Not significant & 0.63 & Not significant \\
\hline \multirow[t]{2}{*}{ Epithelial membrane antigen } & -0.032 & Not significant & 0.30 & Not significant \\
\hline & \multicolumn{2}{|c|}{$r^{2}=0.538$} & \multicolumn{2}{|c|}{ Pseudo $r^{2}=0.4889$} \\
\hline
\end{tabular}

CD34 expression in the stroma around basaloid cells nests; Bcl-2 staining in the peripheral layers of basaloid cell nests; CD10 stromal labeling; cytokeratin 15 expression in the peripheral layers of basaloid cell nests; cytokeratin 20 expression in the peripheral layers of basaloid cell nests; D2-40 expression in the peripheral layers of basaloid cell nests; and epithelial membrane antigen positive in the stroma.

the diagnosis of trichoepithelioma. Both statistical analyses, logistic and linear, favor the utility of stromal CD10 expression in distinguishing trichoepithelioma from basal cell carcinoma. These results support the data obtained by Pham et al. ${ }^{13}$
The results obtained demonstrated that Bcl-2 is not a reliable marker to distinguish trichoepithelioma from basal cell carcinoma tumors. However, in the literature, diffuse Bcl-2 expression by basaliomatous cells was observed in basal cell carcinoma 
Table 4 Discrimination between trichoepithelioma and basal cell carcinoma by association with immunohistochemical markers, ranked according to their significance in multiple models.

\begin{tabular}{|c|c|c|c|c|}
\hline Immunohistochemical marker association & Subset/Results & Trichoepithelioma & Basal cell carcinoma & Discrimination \\
\hline \multicolumn{5}{|l|}{ Labeling Immunohistochemical Group } \\
\hline Group 0 D2-40 & $\begin{array}{l}1 /+ \\
0 /-\end{array}$ & $\begin{array}{l}84 / 128(66 \%) \\
44 / 128(34 \%)\end{array}$ & $\begin{array}{c}16 / 271(6 \%) \\
255 / 271(94 \%)\end{array}$ & $\begin{array}{l}\text { No } \\
\text { No }\end{array}$ \\
\hline Group 1 D2-40/cytokeratin 15 & $\begin{array}{c}2 /+,+ \\
1 /+,- \text { or }-,+ \\
\mathbf{0} /-,-\end{array}$ & $\begin{array}{l}48 / 128(37 \%) \\
59 / 128(46 \%) \\
21 / 128(16 \%)\end{array}$ & $\begin{array}{c}2 / 271(1 \%) \\
46 / 271(17 \%) \\
223 / 271(82 \%)\end{array}$ & $\begin{array}{l}\text { No } \\
\text { No } \\
\text { No }\end{array}$ \\
\hline Group 2 D2-40/cytokeratin 15/CD10 & $\begin{array}{c}\text { 3/+,+,+ } \\
\text { 2/Any ++ } \\
\text { 1/Any + } \\
\mathbf{0} /-,-,-\end{array}$ & $\begin{array}{l}32 / 128(25 \%) \\
54 / 128(42 \%) \\
29 / 128(23 \%) \\
13 / 128(10 \%)\end{array}$ & $\begin{array}{c}0 / 271 \\
10 / 271(4 \%) \\
91 / 271(34 \%) \\
170 / 271(63 \%)\end{array}$ & $\begin{array}{c}25 \% \text { TE } \\
\text { No } \\
\text { No } \\
\text { No }\end{array}$ \\
\hline $\begin{array}{l}\text { Group } 3 \text { D2-40/cytokeratin 15/CD10/ } \\
\text { cytokeratin } 20\end{array}$ & $\begin{array}{c}\text { 4/+,+,+,+ } \\
\text { 3/Any }+,+,+ \\
\geq+,+,+ \\
\text { 2/Any }+,+ \\
\text { 1/Any }+ \\
\text { 0/-,-,-,- }\end{array}$ & $\begin{array}{l}5 / 128(4 \%) \\
41 / 128(32 \%) \\
46 / 128(36 \%) \\
47 / 128(37 \%) \\
23 / 128(18 \%) \\
12 / 128(9 \%)\end{array}$ & $\begin{array}{c}0 / 271 \\
0 / 271 \\
0 / 271 \\
16 / 271(6 \%) \\
89 / 271(33 \%) \\
166 / 271(61 \%)\end{array}$ & $\begin{array}{c}4 \% \text { TE } \\
32 \% \text { TE } \\
36 \% \text { TE } \\
\text { No } \\
\text { No } \\
\text { No }\end{array}$ \\
\hline $\begin{array}{l}\text { Group } 4 \text { D2-40/cytokeratin 15/CD10/ } \\
\text { cytokeratin 20/CD34 }\end{array}$ & $\begin{array}{c}\text { 5/+,+,+,+,+ } \\
\text { 4/Any }+,+,+, \\
2=+,+,+,+ \\
\text { 3/Any }+,+,+ \\
\text { 2/Any }+,+ \\
\text { 1/Any }+ \\
\text { 0/-,-,-,-,- }\end{array}$ & $\begin{array}{c}3 / 128(2 \%) \\
32 / 128(25 \%) \\
35 / 128(27 \%) \\
38 / 128(30 \%) \\
31 / 128(24 \%) \\
16 / 128(12 \%) \\
8 / 128(6 \%)\end{array}$ & $\begin{array}{c}0 / 271 \\
0 / 271 \\
0 / 271 \\
3 / 271(1 \%) \\
34 / 271(12 \%) \\
128 / 271(47 \%) \\
106 / 271(39 \%)\end{array}$ & $\begin{array}{c}2 \% \text { TE } \\
25 \% \text { TE } \\
27 \% \text { TE } \\
\text { No } \\
\text { No } \\
\text { No } \\
\text { No }\end{array}$ \\
\hline
\end{tabular}

CD34 expression in the stroma around basaloid cells nests; stromal CD10 expression; cytokeratin 15 expression in the peripheral layers of basaloid cell nests; cytokeratin 20 expression in the peripheral layers of basaloid cell nests; and D2-40 expression in the peripheral layers of basaloid cell nests.

tumors, while expression of this marker only in the outermost layers of basaloid nests was observed in trichoepithelioma tumors; this difference in Bcl-2 localization was considered feasible for the discrimination between these two basaloid tumors. ${ }^{15-18}$

Trichoepithelioma and basal cell carcinoma tumors displayed different epithelial membrane antigen staining patterns. However, epithelial membrane antigen expression did not reach significant 'Beta' values in the regression analysis.

Despite the low expression of cytokeratin 20, the value of this immune marker was confirmed by logistic and linear regression. Literature addressing the role of cytokeratin 20 in discriminating between trichoepithelioma and basal cell carcinoma is also conflicting. ${ }^{6-10}$ In the present study, inclusion of cytokeratin 20 in immunolabeling panels provided the best ability for identifying trichoepithelioma tumors. This finding suggests that cytokeratin 20 may help to distinguish trichoepithelioma from basal cell carcinoma in the context of an immunohistochemical panel.

Analysis of the logistic regression revealed that cytokeratin 15 expression in the outermost layer of the basaloid nests was the second best marker favoring a trichoepithelioma diagnosis. This pattern is considered to favor the basal cell carcinoma diagnosis. ${ }^{19,20}$

In our series, D2-40 labeling of the peripheral layers of basaloid cell nests was the best identifier of trichoepithelioma tumors.
A logistic regression analysis was used in an attempt to identify the smallest immunohistochemical panel that could discriminate trichoepithelioma from basal cell carcinoma. This statistical test has been used in previous study to test the diagnostic utility of a panel of immune markers to differentiate primary adnexal skin carcinoma from metastatic neoplasms of the skin. ${ }^{21}$

Both the linear and logistic regression analyses showed agreement between the discriminatory patterns and markers better able to distinguish trichoepithelioma from basal cell carcinoma (Table 3 ), but the arrangement of the data in the linear regression study highlights that among the markers used in this work there was not a single marker/ pattern that was completely effective in the differential diagnosis of trichoepithelioma and basal cell carcinoma. Although the data from D2-40 labeling pattern was considered the best identifier of trichoepithelioma tumors, this marker is not entirely reliable because in our series 16 basal cell carcinoma biopsies only expressed this antigen (see Table 4).

These observations may explain the contradictory results found in various reports addressing immune markers for differentiating between trichoepithelioma and basal cell carcinoma. The data displayed in Table 4 enhance the utility of a panel of markers expressed in the stroma and neoplastic cells to improve the discrimination between trichoepithelioma and basal cell carcinoma. Other authors built panels with epithelial markers or the association of 
epithelial and stromal markers. ${ }^{11,12,16}$ In this work, the more effective panel was built using data obtained from a linear regression analysis and was composed of at least one marker displaying stromal labeling.

The results obtained in this work displayed and confirmed the overlap between the stromal and epithelial immunohistochemical profiles of trichoepithelioma and basal cell carcinoma tumors. It also corroborated the point of view that trichoepithelioma and basal cell carcinoma tumors are in two different points in the differentiation of a single cell line. ${ }^{10,12,20}$ Additionally, our study displayed a subset of $36 \%$ trichoepithelioma tumors that could be diagnosed only by their immune marker profile. Despite the value of immune marker panels, histopathological criteria associated with clinical data certainly remains the best guideline for the differential diagnosis of trichoepithelioma and basal cell carcinoma.

\section{Acknowledgement}

This work was supported by CAPES-PROAP. We thank Dr Fernando Soares, MD and Dr Rafael Malagoli, BSc, PhD from the Instituto A. C. Camargo, São Paulo, for scanning the slides.

\section{Disclosure/conflict of interest}

The authors declare no conflict of interest.

\section{References}

1 Carr RA, Taijbee SM, Sanders DSA. Basaloid skin tumours: basal cell carcinoma. Curr Diagn Pathol 2007;13:252-272.

2 Kirschman TT, Prieto VC, Smoller BR. CD34 stainig pattern distinguishes basal cell carcinoma from trichoepithelioma. Arch Dermatol 1994;130:589-592.

3 Illueca C, Monteagudo C, Revert A, et al. Diagnostic value of CD34 immunostaining in desmoplastic trichilemmoma. J Cutan Pathol 1998;25:435-439.

4 Swanson PE, Fitzpatrick MM, Ritter JH, et al. Immunohistologic differential diagnosis of basal cell carcinoma, squamous cell carcinoma, and trichoepithelioma in small cutaneous biopsy specimens. J Cutan Pathol 1998;25:153-159.

5 Basarab T, Orchard G, Russel l-Jones R. The use of immunostaining for Bcl-2 and CD34 and the lectin peanut agglutinin in differentiating between basal cell carcinomas and trichoepitheliomas. Am J Dermatopathol 1998;20:448-452.

6 Schulz T, Hartschuch W. Merkel cells are absent in basal cell carcinomas but frequently found in trichoblastomas. An immunohistochemical study. J Cutan Pathol 1997;24:14-24.
7 Abeasamis-Cubillan E, El-Shabrawi-Caelen L, LeBoit PE. Merkel cells and sclerosing epithelial neoplasms. Am J Dermatopathol 2000;22:311-315.

8 Costache M, Bresch M, Böer A. Desmoplastic trichoepithelioma versus morphoeic basal cell carcinoma: a critical reappraisal of histomorphological and immunohistochemical criteria for differentiation. Histopathol 2008;52:865-876.

9 Katona TM, Perkins SM, Billings SD. Does the panel of cytokeratin 20 and androgen receptor antibodies differentiate desmoplastic trichoepithelioma from morpheaform/infiltrative basal cell carcinoma? J Cutan Pathol 2008;35:174-179.

10 Schirren CG, Rütten A, Kaudewitz P, et al. Trichoblastoma and basal cell carcinoma are neoplasms with follicular differentiation sharing intermediate filaments. Am J Dermatopathol 1998;19:341-350.

11 Yamamoto O, Asahi M. Cytokeratin expression in trichoblastic fibroma (small nodular type of trichoblastoma), trichoepithelioma and basal cell carcinoma. Br J Dermatol 1999;140:8-16.

12 Ohnishi T, Watanabe S. Immunohistochemical analysis of cytokeratin expression in various trichogenic tumors. Am J Dermatopathol 1999;21:337-343.

13 Pham TT, Selim MA, Burchette Jr JL, et al. CD10 expression in trichoepithelioma and basal cell carcinoma. J Cutan Pathol 2006;33:123-128.

14 Plaza JA, Ortega PF, Bengana C, et al. Immunolabeling pattern of podoplanin (D2-40) may distinguish basal cell carcinomas from trichoepitheliomas: a clinicopathologic and immunohistochemical study of 49 cases. Am J Dermatopathol 2010;32:683-687.

15 Smoller BR, Van de Rijn M, Lebrun D, et al. Bcl-2 expression reliably distinguishes trichoepitheliomas from basal cell carcinomas. Br J Dermatol 1994;131: 28-31.

16 Poniecka AW, Alexis JB. An immunohistochemical study of basal cell carcinoma and trichoepithelioma. Am J Dermatopathol 1999;21:332-336.

17 Abdelsayed RA, Guijarro-Rojas M, Ibrahim NA, et al. Immunohistochemical evaluation of basal cell carcinoma and trichoepithelioma using Bcl-2, Ki67, PCNA and P53. J Cutan Pathol 2000;27:169-175.

18 Córdoba A, Guerrero D, Larrinaga B, et al. Bcl-2 and CD10 expression in the differential diagnosis of trichoblastoma, basal cell carcinoma, and basal cell carcinoma with follicular differentiation. Int J Dermatol 2009;48:713-714.

19 Choi CW, Park HS, Kim YK, et al. Elastic fiber staining and cytokeratin 15 expression pattern in trichoepithelioma and basal cell carcinoma. J Dermatol 2008;35:499-502.

20 Jih DM, Lyle S, Elenitsas R, et al. Cytokeratin 15 expression in trichoepitheliomas and a subset of basal cell carcinomas suggests they originate from hair follicle stem cells. J Cutan Pathol 1999;23:113-118.

21 Mahalingam M, Nguyen LP, Richards JE, et al. The diagnostic utility of immunohistochemistry in distinguishing primary skin adnexal carcinomas from metastatic adenocarcinoma to skin: an immunohistochemical reappraisal using cytokeratin 15, nestin, p63, D2-40, and calretinin. Mod Pathol 2010;23: $713-719$. 